термінологія» для студентів спеціальностей «Лісове господарство» та «Деревооброблювальні технології».

\title{
Література
}

1. Бондаренко Г. П. Методика навчання студентів економічних спеціальностей української наукової термінології в умовах східного регіону України : автореф. дис. на здобуття наук. ступеня канд. пед. наук : спец. 13.00.02 «Теорія і методика навчання української мови» / Г. П. Бондаренко. - Київ, 2008. - 21 с. 2. Вікторова Л. В. Формування професійно-термінологічної компетентності студентів вищих аграрних навчальних закладів у фаховій підготовці : автореф. дис. на здобуття наук. ступеня канд. пед. наук : спец. 13.00.04 «Теорія i методика професійної освіти»/ Л. В. Вікторова. - Чернігів, 2009. - 23 с. 3. Денищич T. Спеціальні та власне методичні принципи формування термінологічної компетентності майбутніх соціологів [Електронний ресурс] / Т. Денищич // Збірник наукових праць Уманського державного педагогічного університету. - 2014. - Ч. 2. - С. 113-120. Режим доступу до докум. : http://nbuv.gov.ua/ UJRN/znpudpu_2014_2_17. 4. Денищич Т. А. Формування термінологічної компетентності майбутніх фахівців 3 політології [Електронний pecypc] / Т. А. Денищич // Наукові праці [Чорноморського державного університету імені Петра Могили комплексу «Києво-Могилянська академія»]. Сер. : Педагогіка. - 2012. T. 209. - Вип. 197. - С. 137-142. - Режим доступу до докум. : http://nbuv.gov.ua/UJRN/ Npchduped_2012_209_197_28. 5. Ермолаева Ж. Е. О формировании терминологической культуры обучающихся в вузах МЧС России / Ж. Е. Ермолаева // Технологии техносферной безопасности. - 2014. - Вып. № 5 (57). - Режим доступа к докум. : http://ipb.mos.ru/ttb/20145/2014-5.html. 6. Огар Е. I. Українська видавнича термінологія : нормалізаційні та функціональні аспекти [Електронний ресурс] / Е. І. Огар.- Режим доступу до докум. : http://journlib.univ.kiev.ua/index.php?act=article\&article=2399. 7. Пентилюк М. Розвиток української лінгводидактики в контексті державного стандарту базової і повної освіти в Україні / М. Пентилюк. - Вісник Львів. університету. Серія філологічна. - 2010. - Вип. 50. С. 123-130. 8. Психологічна енциклопедія / авт.-упор. О. М. Степанов. - Київ : Академвидав, 2006. - 424 с. 9. Рашкевич Ю. М. Болонський процес та нова парадигма вищої освіти: [монографія] / Ю. М. Рашкевич. - Львів : Видавництво Львівської політехніки, 2014. - 168 с. 10. Симоненко Т. В. Теорія i практика формування професійної мовнокомунікативної компетенції студентів філологічних факультетів : [монографія] / Т. В. Симоненко. - Черкаси, 2006. - 328 с. 11. Тоцька Н. Методика роботи викладачів вищого технічного навчального закладу над українським професійним мовленням студентів / Н. Тоцька // Дивослово. 2003. - № 1. - С. 62-65.

УДК 378.1:687

Вікторія Желанова

\section{КОНТЕКСТУАЛІЗАЦІЯ ПРОФЕСІЙНОЇ ПІДГОТОВКИ ДИЗАЙНЕРІВ ОДЯГУ У ВНЗ}

\footnotetext{
Желанова В. В. Контекстуалізація професійної підготовки майбутніх дизайнерів одягу у ВНЗ.

У представленій статті розглянуто принцип контекстуалізації у форматі професійної підготовки дизайнерів одягу у ВНЗ. Висвітлено концептуальні засади контекстуалізації професійної підготовки майбутніх дизайнерів одягу. Подано дефініції поняття «контекстний підхід», «контекст», «професійний контекст». Обгрунтовано феномен «професійний контекст майбутнього дизайнера одягу» й розглянуто його структуру, що містить мотиваційноціннісний, творчо-проектувальний, виробничий контексти. Розкрито змістову площину контекстуалізації. Проаналізовано організаційні аспекти контекстуалізації, що пов’язані 3 упровадженням певного педагогічного інструментарію контекстної спрямованості.
} 
Ключові слова: контекстний підхід, контекстуалізація, контекст, професійний контекст, професійний контекст майбутнього дизайнера одягу, мотиваційно-ціннісний контекст, творчо-проектувальний контекст, виробничий контекст.

Желанова В. В. Контекстуализация професиональной подготовки будущих дизайнеров одежды в вузе.

В представленной статье рассмотрен принцип контекстуализации в формате профессиональной подготовки дизайнеров одежды в вузах. Освещены концептуальные основы контекстуализации профессиональной подготовки будущих дизайнеров одежды. Подано дефиниции понятий «контекстный подход», «контекст», «профессиональный контекст». Обоснованно феномен «профессиональный контекст будущего дизайнера одежды» и рассмотрена его структура, содержащая мотивационно-ценностный, творческопроектировочный, производственный контексты. Раскрыта содержательная сфера контекстуализации. Проанализированы организационные аспекты контекстуализации, связанные с использованием педагогического инструментария контекстной направленности.

Ключевые слова: контекстный подход, контекстуализация, контекст, профессиональный контекст, профессиональный контекст будущего дизайнера одежды, мотивационноценностный контекст, творческо-проектировочный контекст, производственный контекст.

Zhelanova V. V. The contextualization of professional training of the future fashion designers in higher educational institutions.

In the article the problem of specialists training in design sphere in higher educational institutions is substantiated. The Modern Discourse Studies of contextualization of professional training problems is indicated. The essence of the contextualization phenomenon is analyzed as a basic principle of modern education. The principle of contextualization is represented in formate of the professional training of fashion designers at universities. The conceptual principles of contextualization of professional training of future fashion designers are shown. The concepts «contextual approach», «context», «professional context» are defined. The phenomenon «professional context of the future fashion designer» and its structure are grounded. The professional context of the future fashion designer is represented by complex of motives, installations, value relations for the process and outcome of clothes designing. It was found that motivational-value context reflects the incentive aspects of professional work of fashion designer. It is associated with personal interest, desire, propensity to engage in apparel design, an approach to the labor itself as a value. It is a set of motives, attitudes, values, relationship to the process and outcome of designing clothes. Creative and projecting context reflects the stage of designing clothes, namely: pre-search related to the analytical work (analysis of consumer needs, his anthropometric data, diagnosis of psychological personality traits, analysis of manufacturing of technical and economic requirements), the image designing (includes shaping and development of color palette) production context associated with the production of clothing technology (process context) and communication subjects in this process (the communicative context). The conceptual scope of contextualization is solved. The organizational aspects of contexstualization related using definitely teaching tool are represented. The teaching tool is provided by imitative and not imitative forms of organizational learning.

Key words: contextual approach, contextualization, context, professional context of the future fashion designer, motivational-value context, creative-projecting context, productional context.

Актуальність проблеми професійної підготовки фахівців 3 дизайну одягу зумовлена глибинними й стрімкими політичними, соціально-економічними, інноваційно-освітніми трансформаціями в житті України, а також глобалізаційними процесами, пов'язаними 3 орієнтацією нашої держави на інтеграцію із світовою спільнотою. Саме ці риси сучасного суспільства посилили проблему високої конкуренції на ринку праці серед випускників ВНЗ, зокрема фахівців 3 дизайну одягу. При цьому варто відзначити, що незважаючи на економічні ускладнення в Україні, сфера індустрії одягу має стійку тенденцію до зростання і 
$\epsilon$ галуззю з високим рівнем конкуренції. Проте стан справ у ній, темпи та глибина перетворень не повною мірою задовольняють потреби особистості, суспільства й держави. Тобто постає необхідність підвищення якості підготовки фахівця з дизайну одягу у ВНЗ, здатного до створення та впровадження новітніх прийомів роботи, вивчення і застосування інноваційних технологій. При цьому у процесі модернізації вищої освіти в Україні дедалі більшої ваги набувають освітні системи, що дозволяють побудувати навчання відповідно до особливостей майбутньої професійної діяльності шляхом моделювання ії̈ контексту. Отже, $є$ очевидним, що контекстуалізація сучасної вищої освіти стає ії базовим принципом, який отримав практичну реалізацію в системі контекстного навчання у ВНЗ.

Зазначений принцип було обгрунтовано ще С. Рубінштейном. Відомий психолог довів, що будь-який досліджуваний предмет, явище неможливо розглядати поза контекстом їхнього існування та застосування, так само, як не можна розглядати існування й діяльність людини поза соціальних і виробничих відносин, що іiі оточують [4]. На думку відомого дослідника контекстної проблематики А. Вербицького, цей принцип є грунтовним щодо контекстного підходу, який трактується науковцем як підпорядкування змісту й логіки вивчення навчального матеріалу виключно інтересам майбутньої професійної діяльності, унаслідок чого навчання набуває усвідомленого, предметного, контекстного характеру, сприяючи посиленню пізнавального інтересу й пізнавальної активності студентів [1].

Сучасний науковий дискурс репрезентує дослідження проблеми контектуалізації професійної підготовки у форматі компетентнісного (А. Вербицький, О. Срмакова, О. Ларіонова), діяльнісного (Н. Пророк, І. Тиханкіна), інтегративного (О. Ларіонова, В. Тєніщева), індивідуального (Н. Смирнова), модульно-контекстного (Л. Костельна, С. Литвинчук), домінантно-контекстного (О. Касатиков), проектно-контекстного (О. Мачехіна), середовищного (О. Щербакова), ситуаційно-контекстного (М. Ільязова), справожиттєвого (О. Ткаченко), рефлексивно-контекстного (В. Желанова) наукових підходів. Концептуальні основи контекстного навчання були обгрунтовані у дослідженнях А. Вербицького. Відомі роботи щодо різних напрямів впровадження контекстного навчання в математичну освіту (О. Ларіонова, М. Макарченко), в іншомовну підготовку майбутніх фахівців (О. Григоренко, Ю. Маслова, О. Самсонова, О. Трунова, Н. Хомякова, С. Яцишина) у підготовку майбутнього вчителя початкових класів (В. Желанова). Проте при такій високій зацікавленості різними аспектами контекстної проблематики, питання, пов'язані 3 контекстуалізацією професійної підготовки дизайнерів одягу, залишаються поза увагою науковців. Хоча у теорії професійної освіти порушено певні проблеми дизайн-освіти, розкрито передумови формування вмінь та навичок в дизайні (А. Новикова, В. Чебишева); обгрунтовано положення, що удосконалення професійної підготовки майбутніх дизайнерів одягу є невід'ємним складником модернізації освіти в Україні й висвітлено певні особливості професії дизайнера одягу (Е. Андреєва, Т. Макарова, I. Продан, I. Стар, А. Черемних); обгрунтовано модель професійної діяльності конкретних фахівців-дизайнерів одягу (Н. Зимогляд); розглянуто проблему професійної підготовки дизайнерів одягу (С. Леонович, Л. Матвєєва, В. Сидоренко).

Метої статmі є висвітлення феномену контекстуалізації у форматі професійної підготовки майбутнього дизайнера одягу.

Як відомо, дизайн як особлива творча проектна діяльність виник у галузі промисловості у зв'язку 3 розвитком масового виробництва товарів. Його метою було подолання розриву між красою й користю, між мистецтвом і технікою [3]. При цьому проектування тлумачилося не як механічне стандартизоване виконання ескізів, креслень, а творчий процес, який може змінюватися залежно від об'єкта та умов діяльності.

Метою дизайну як феномену сучасної культури є сприяння підвищенню якості життя людей і вдосконалення соціально-культурних відносин між ними шляхом формування гармонійного предметного середовища для задоволення матеріальних $\mathrm{i}$ духовних потреб людей.

Варто відзначити, що останнім часом набуває поширення такий напрям дизайн- 
діяльності як дизайн одягу. Його ціллю є проектування одягу, який відповідає вимогам користі, зручності експлуатації та краси [2].

А. Сушан зауважує, що специфіка дизайну одягу полягає в тому, що швейний виріб $є$ одночасно предметом декоративного мистецтва та об'єктом промислового виготовлення [5]. Тому при створенні технології процесу проектування швейних виробів $\epsilon$ актуальним поєднання творчого та інженерного компонентів. Тобто у процесі дизайнерської діяльності органічно поєднуються естетичне і виробниче начало для досягнення гармонії у створенні матеріальних цінностей.

Отже, $є$ очевидним, що дизайн-освіта, спрямована на підготовку фахівців цього профілю має відбуватися з урахуванням контексту майбутньої професії.

Розглянемо концептуальні засади контекстуалізаиї професійної підготовки майбутніх дизайнерів одягу. Загалом погоджуючись з відомими дослідниками контекстної проблематики, наголосимо на кількох важливих для дослідження моментах:

1. Контекстуалізацію професійної підготовки майбутніх дизайнерів одягу будемо висвітлювати у трьох площинах: конщептуальній, змістовій, організаційній.

2. Трактування контекстуалізаиії професійної підготовки дизайнера одягу пов'язане 3 iï тлумаченням як принципу, який передбачає інтеграцію знань, умінь, навичок, особистісних якостей, що формуються у процесі навчання, зміст якого побудований з урахуванням соціальних та предметних особливостей професійного контексту.

3. Досліджуючи проблему контекстуалізації професійної підготовки майбутніх дизайнерів одягу, ми грунтуємося на контекстному науковому nidxодi, що $є$ підпорядкуванням змісту й логіки вивчення навчального матеріалу виключно інтересам майбутньої професійної діяльності, унаслідок чого навчання набуває усвідомленого, предметного, контекстного характеру, сприяючи посиленню пізнавального інтересу й пізнавальної активності студентів.

4. Загальновідомо, що будь-який науковий підхід як засіб концептуалізації знань визначається певною ідеєю, концепцією й центрується провідною для нього однією або кількома категоріями (Г. Корнетов). Щодо контекстного підходу такими є поняття «контекст» й у нашому випадку «професійний контекст майбутніх дизайнерів одягу». Отже, розглянемо їх.

Варто відзначити, що поняття «контекст» $\epsilon$ одним 3 найбільш продуктивних міждисциплінарних феноменів, що часто використовується в лінгвістиці, психолінгвістиці, логіці, філософії. Але в сучасний період розвитку науки поняття «контекст» виходить за межі традиційного трактування й фактично постає як загальнонаукова, зокрема психологічна та педагогічна, категорія, опора на яку, як доводить А. Вербицький, відкриває нові перспективи в науковому пізнанні й освітній практиці [1].

У педагогіку поняття «контекст» уведено порівняно недавно, тому воно ще не набуло певного статусу й у педагогічних словниках не описується. Педагогічні аспекти категорії «контекст» найбільш вдало розкрито в дослідженнях А. Вербицького та представників його наукової школи (Н. Борисова, Н. Жукова). На думку науковця, контекст - це система внутрішніх і зовнішніх умов та чинників поведінки й діяльності людини, яка впливає на сприйняття, розуміння й перетворення суб'єктом конкретної ситуації, що визначає смисл та значення цієї ситуації як цілого, так і певних її компонентів [1, с. 33-34]. Поняття «професійний контекст» із загальнопрофесійних позицій також досліджено А. Вербицьким. Він розглядає зазначене поняття як смислоутворювальну категорію, що впливає на процес оволодіння реальною предметною діяльністю завдяки наданню їй особистісного смислу.

Відтак, професійний контекст майбутніх дизайнерів одягу є системою значущих контекстів професійної спрямованості, структура якої представлена мотиваційно-ціннісним, творчо-проектувальним, виробничим контекстами. При цьому мотиваційно-ціннісний контекст тлумачиться нами як внутрішній; творчо-проектувальний- $\epsilon$ синтезом внутрішнього й зовнішнього; виробничий - є зовнішнім контекстом. Розглянемо їх ретельніше. 
- Мотиваційно-изіннісний контекст відбиває спонукальні аспекти професійної діяльності дизайнера одягу й пов'язаний 3 потребою, особистісною зацікавленістю, прагненням, схильністю займатися проектуванням одягу, з підходом до змісту самої праці як цінності. Він є сукупністю мотивів, установок, ціннісних ставлень до процесу та результату проектування одягу.

- Творчо-проектувальний контекст відбиває стадії проектування одягу, а саме:

1. Передпроектний пошук, що пов'язаний з аналітичною діяльністю (аналіз потреб споживача, його антропометричних даних, діагностування психологічних особливостей особистості; аналіз виробничих техніко-економічних вимог).

2. Проектний образ - концепція, що $\epsilon$ інтеграцією образу споживача та образу майбутнього одягу.

3. Розробка ескизу одягу, що передбачає формоутворення й розробку колористичного рішення. Варто відзначити, що кольорове рішення одягу визначається дизайнером одночасно 3 формоутворенням [2].

- Виробничий контекст пов'язаний з технологією виробництва одягу (технологічний контекст) і спілкуванням суб'єктів зазначеного процесу (комунікативний контекст).

Змістова площина контекстуалізації. Отже, розглянемо змістові аспекти контектуалізації професійної підготовки майбутнього дизайнера одягу. Звернемо увагу, що вони суттєво відрізняються від уявлення про зміст освіти у традиційній дидактиці. У зоні первинної уваги є особистість студента, його діяльність і внутрішнє освітнє зростання та розвиток. Відповідно, зміст освіти поділяється на зовнішній (середовище) та внутрішній, що створюється при взаємодії із середовищем. Отже, наведене трактування змісту освіти пов'язане з розглядом його не як предмета засвоєння, а як зовнішнього складника освіти, що виконує функції середовища для внутрішніх змін особистості.

Відзначимо, що ключовим аспектом змісту освіти у процесі його контекстуалізації $є$ професійний досвід дизайнера одягу і процес його інтеріоризації. При цьому правомірним $\epsilon$ виокремлення актуального досвіду як досвіду студента, що набувається безпосередньо в умовах освіти, та потенційного досвіду - як досвіду майбутньої професійної діяльності дизайнера одягу, набуття якого відбувається під впливом актуального досвіду. Зауважимо, що близьким саме до цих позицій є проектування змісту освіти відповідно до вимог майбутньої професійної діяльності та проблемного підходу до навчання (Н. Борисова, А. Вербицький, О. Ларіонова).

Отже, підсумовуючи сказане вище, зробимо висновок, що наведені положення відтворюють логіку процесу переходу від «знаннєвого» до середовищно зорієнтованого, а також спрямованого на інтеріоризацію професійного досвіду змісту освіти майбутнього дизайнера одягу у процесі його контекстуалізації.

Організаційні аспекти контекстуалізащії. 3'ясуємо організаційні аспекти контекстуалізації професійної підготовки майбутнього дизайнера одягу. Зауважимо, що вони пов'язані з упровадженням певного педагогічного інструментарію контекстної спрямованості, що $є$ сукупністю певних форм і методів, алгоритмів педагогічної взаємодії викладача та студентів, а також студентів між собою у процесі професійної підготовки. Він містить імітаційні та неімітаційні форми організації навчання, тобто відповідно ті, що базуються на імітаційних (моделювання середовища, певної ситуації діяльності) або неімітаційних (відсутнє моделювання) методах навчання.

Отже, розглянемо неімітаційні форми організації навчання, якими є лекційні заняття. Зауважимо, що лекція контекстного типу має свої особливості й переваги, що відрізняють іiі від традиційної лекції. Провідна перевага лекції контекстного типу полягає в іiі професійній орієнтації, активній участі студентів у процесі навчання, а також у пріоритеті колективних форм роботи. Різновиди лекцій контекстного типу розроблені А. Вербицьким [1]. У нашому дослідженні ми їх розглядаємо в модифікованому вигляді.

Нами також накопичено досвід використання тренінгових занять з використанням, так званої, «нарізки» певних компонентів проектування. Додамо, що у процесі роботи 3 
відеоматеріалами можливе впровадження комунікативного контексту засобом спрямованого аналітичного спостереження за реальним процесом проектування одягу.

У педагогічному інструментарії контекстної спрямованості особливе місце посідають імітаційні форми організації навчання, що базуються на активній навчально-пізнавальній діяльності, у якій студент отримує можливість освоєння цілісної професійної діяльності або великих фрагментів у процесі іiі імітації. Своєю чергою, імітаційні форми організації навчання поділяються на ігрові й неігрові. Уточнимо, що в неігрових формах навчання імітується переважно лише якийсь бік предмета навчання. Ігрові ж форми навчання будуються на його імітації у вигляді гри за певними правилами. Саме такою є ділова гра.

Зауважимо, що вона має очевидні переваги, а саме: застосування ділових ігор у системі професійної підготовки майбутніх дизайнерів одягу у ВНЗ надає змогу максимально наблизити навчальний процес до професійної діяльності, урахувати реалії сучасного дізайну; студент у спеціально створених умовах «проживає» різноманітні ситуації, які дають йому змогу формувати світогляд, уміння приймати рішення в умовах конфліктних ситуацій, відстоювати свої пропозиції, розвивати навички спільної колективної роботи.

Далі розглянемо неігрові імітаційні форми організації навчання, якими $є$ аналіз професійних ситуацій та розв’язання професійних задач. Зазначимо, що до наукового обігу нами введено та обгрунтовано поняття професійної задачі контекстної спрямованості, у якій відтворюється зміст майбутньої професійної діяльності та здійснюється загальний i професійний розвиток особистості майбутнього фахівця. Ми обгрунтовуємо такі типи задач контекстного типу, як-от: мотиваційні задачі, що виконують спонукальну функцію; задачі смислової спрямованості, що сприяють професійному смислоутворенню та дозволяють студентові здійснити смисловий вибір; задачі суб'єктної спрямованості, що створюють умови для реалізації професійної суб'єктності.

Отже, контекстуалізація професійної підготовки є провідним принципом сучасної вищої освіти, який спрямований на створення ще на етапі вишівської підготовки умов, які забезпечують майбутнім дизайнерам одягу ефективний перехід від навчальної до професійної діяльності, успішну інтеграцію в середовище сучасного виробництва одягу завдяки спеціально спроектованим інформаційним, знаковим моделям і формам навчальної діяльності, що сприяють перетворенню знань з предмета навчальної діяльності на засіб регуляції професійної діяльності, трансформації пізнавальних мотивів у професійні, які поступово набувають статусу особистісної цінності як вагомого стійкого смислового утворення майбутнього фахівця.

Контекстуалізація професійної підготовки майбутнього дизайнера одягу відбувається у трьох площинах, а саме: концептуальній, змістовій, організаційній. При цьому концептуальна грунтується на контекстному науковому підході, на трактуванні професійного контексту майбутнього дизайнера одягу як інтеграції мотиваційно-ціннісного, творчопроектувального, виробничого професійних контекстів. Змістові аспекти контектуалізації професійної підготовки майбутнього дизайнера одягу пов'язані 3 цілісним досвідом професійної діяльності, інтеріоризація якого відбувається в процесі контекстного навчання. Організаційна площина контекстуалізації спрямована на впровадження у процес професійної підготовки організаційних форм навчання контекстної спрямованості, якими $є$ лекції контекстного типу, ділові ігри, професійні задачі контекстної спрямованості. Подальшого дослідження потребує питання щодо створення контекстного освітнього середовища як вагомої умови ефективної контекстуалізації професійної підготовки майбутнього дизайнера одягу у ВНЗ. Саме цей аспект реалізації принципу контекстуалізації буде предметом наших подальших наукових розвідок.

\section{Література}

1. Вербицкий А. А. Новая образовательная парадигма и контекстное обучение / А. А. Вербицкий. - Москва : Исслед. центр проблем качества подготовки специалистов, 1999. - 75 с. 2. Зимогляд Н. С. Модель професійної діяльності дизайнера одягу 3 проектування швейних виробів / Н. С. Зимогляд // Проблеми інженерно-педагогічної освіти, 
2010, № 28/29 - С. 48-57. 3. Розенсон И. А. Основы теории дизайна: [учеб. для вузов] / И. А. Розенсон. - Санкт-Петербург : Питер, 2006. - 219 с. 4. Рубинштейн С. Л. Основы общей психологии : в 2 т. / С. Л. Рубинштейн. - Москва : Педагогика, 1989. - Т. 1. - 486 с. 5. Сушан А. Т. Інженерне проектування швейних виробів : [навч. посіб.] / А. Т. Сушан. Київ : Арістей, 2005. - 172 с.

УДК 81’243:378.147

Вікторія Лапіна

\section{СПЕЦИФІКА ОРГАНІЗАЦІЇ ІНШОМОВНОЇ ПІДГОТОВКИ СТУДЕНТІВ ТЕХНІЧНИХ СПЕЦІАЛЬНОСТЕЙ НА ЗАСАДАХ ДІАЛОГІЧНОГО НАВЧАННЯ}

Лапіна В. О. Специфіка організації іншомовної підготовки студенів технічних спеціальностей на засадах діалогічного навчання.

У статті розглянуто особливості організації діалогічного навчання іноземних мов на засадах педагогіки співпраці в контексті іншомовної підготовки студентів технічних вишів, які сприяють максимальній реалізації дидактичного потенціалу навчального діалогу як ефективного засобу формування тих чи тих навичок і вмінь.

Ключові поняття: діалогічне навчання, навчальний діалог, іншомовна підготовка, студенти технічних спеціальностей.

Лапина В. А. Специфика организации иноязычной подготовки студентов технических специальностей на основе диалогического обучения.

В статье рассмотрены особенности организации диалогического обучения иностранным языкам на принципах педагогики сотрудничества в контексте иноязычной подготовки студентов технических вузов, которые способствуют максимальной реализации дидактического потенциала учебного диалога как эффективного средства формирования тех или иных навыков и умений.

Ключевые понятия: диалогическое обучение, учебный диалог, иноязычная подготовка, студенты технических специальностей.

Lapina V. O. Specifics of a foreign language training organization of students of technical specialties based on dialogic teaching.

The peculiarities of a dialogic teaching organization of foreign languages based on cooperative pedagogy in the context of a foreign language training of students of technical higher educational institutions have been considered in the article. They contribute to maximum realization of didactic potential of educational dialogue as an effective means of forming and developing some skills.

The key features of teaching foreign languages by using dialogic means of learning in technical higher educational institutions (communicative oriented approach; problematic content/context of didactic material; case-study learning activity; active methods and forms of teaching) have been highlighted.

The scientific works on communicative aspect of learning have been analyzed, that allowed to examine this issue in the context of a dialogic teaching of foreign languages and to highlight communication as its key feature.

The various aspects of a problem-based teaching of foreign languages organized and based on the pedagogy of cooperation have been studied. Such learning process is characterized by a high level of problems and is implemented by a system of problem-solving tasks. Students acquire new knowledge, develop intellectual, speech and communication skills and creativity through/by activation of thinking while self-defining and solving problems.

A case-study approach has been highlighted as one of the key feature of a dialogic teaching of foreign languages, which is an effective means of speech activity stimulation. It contributes to students' awareness of real social and professional situations for realizing foreign language 